\title{
PERBANDINGAN KINERJA REKSADANA SYARIAH DAN REKSADANA NON-SYARIAH DI INDONESIA BERDASARKAN RETURN, RESIKO, DAN KOEFISIEN VARIASI")
}

\author{
Shafira Sa'adah Syauqiyah \\ Mahasiswa Program Studi S1 Ekonomi Islam Fakultas Ekonomi dan Bisnis Universitas Airlangga \\ Email: shafirasyq@gmail.com
}

Muhammad Nafik H. R.

Departemen Ekonomi Syariah Fakultas Ekonomi dan Bisnis Universitas Airlangga

Email: muhammadnafik@yahoo.com

\begin{abstract}
This research aims to find out the performance comparison between sharia mutual funds and non-sharia mutual funds in Indonesia during 2013-2015 by using return, risk, and coefficient of variation in the three types of mutual funds; equity mutual fund, mixed mutual fund, and fixed income mutual fund. The approach used is quantitative approach by using independent samples t-test or mann whitney in the test analysis with 5\% significant level. The result of this study indicate that there is no significant difference between return, risk, and coefficient of variation of sharia mutual funds and non-sharia mutual funds in Indonesia in three types of mutual funds.
\end{abstract}

\section{Keywords: Return, Risk, Coefficient of Variation, Sharia Mutual Fund, Conventional Mutual Fund}

\section{PENDAHULUAN}

Investasi merupakan salah satu bentuk penanaman modal yang dilakukan investor yang akan mendatangkan return dikemudian hari. Definisi investasi menurut Tandelilin (2010:2) adalah komitmen atas sejumlah dana atau sumber daya lainnya yang dilakukan pada saat ini, dengan tujuan memperoleh sejumlah keuntungan di masa datang.

Dalam Islam, investasi merupakan salah satu aktivitas muamalah yang diperbolehkan dan sangat dianjurkan. Ryandono (2009:70) mendefinsikan investasi yang Islami adalah pengorbanan sumber daya pada masa sekarang untuk mendapatkan hasil yang pasti, dengan harapan memperoleh hasil yang lebih besar dimasa yang akan datang, baik langsung maupun tidak langsung seraya tetap berpijak pada prinsip-prinsip syariah secara menyeluruh (kaffah).

Investasi merupakan salah satu cara untuk membuat harta kita menjadi produktif dan menjadi salah satu wujud agar tidak terjadinya penimbunan harta (ikhtikar) yang bertujuan untuk merusak suatu pasar. Dalam Islam, ikhtikar dilarang karena dapat mendzolimi orang lain. Rasulullah SAW bersabda:

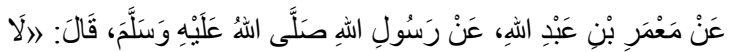

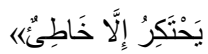
'an Ma'mar ibn Abdillah, 'an Rasūli Allāhi Salla Allāhu 'Alaihi wa Sallama, Qāla: "Iā Yahtakiru illā Khātiun

Artinya: Barangsiapa yang menimbun, maka dia telah berbuat dosa. (HR. Muslim)

Pada umumnya, investasi dapat dilakukan pada dua jenis aset, yaitu real asset dan financial asset (Huda dan Nasution, 2007:8). Investasi pada real asset 
Syauqiyah, et al/ Jurnal Ekonomi Syariah Teori dan Terapan Vol. 5 No. 2 Februari 2018: 123-

134; PERBANDINGAN KINERJA REKSADANA SYARIAH DAN REKSADANA NON-SYARIAH DI

INDONESIA BERDASARKAN RETURN, RESIKO, DAN KOEFISIEN VARIASI

dapat dilakukan dengan cara membeli menerbitkan reksadana syariah berjenis aset produktif, seperti membangun pabrik, membeli tanah, dll. Sedangkan investasi pada financial asset dapat dilakukan di pasar vang untuk instrumen keuangan yang mempunyai jangka waktu relatif pendek dan pasar modal untuk investasi jangka panjang.

Investasi surat-surat berharga, seperti saham, reksadana, sukuk, dan lainnya dapat dilakukan di Pasar Modal. Manan (2009:13) mendefinisikan pasar modal adalah pasar untuk berbagai instrumen keuangan jangka panjang yang bisa diperjualbelikan, baik dalam bentuk utang maupun modal sendiri.

Pasar Modal memiliki beberapa instrumen investasi yang dapat dipilih investor, salah satunya adalah reksadana. UU Pasar Modal no. 8 Tahun 1995 Pasal 1 Ayat 27 mendefinisikan reksadana adalah wadah yang digunakan untuk menghimpun dana dari masyarakat pemodal untuk selanjutnya diinvestasikan dalam portofolio efek oleh Manajer Investasi. Hirt dan Block (1999:536) menyatakan keuntungan berinvestasi pada reksadana adalah karena reksadana menawarkan cara yang efisien untuk mendiversifikasikan investasi. Reksadana juga memiliki manajer investasi sebagai pengelola investasi.

Reksadana muncul pertama kali di Indonesia dimulai pada tahun 1976, yaitu pendirian reksadana oleh pemerintah dengan nama PT. Danareksa yang mempunyai sertifikat bernama danareksa. Pada tahun 1997, PT Danareksa 
Syauqiyah, et al/ Jurnal Ekonomi Syariah Teori dan Terapan Vol. 5 No. 2 Februari 2018: 123-

134; PERBANDINGAN KINERJA REKSADANA SYARIAH DAN REKSADANA NON-SYARIAH DI

INDONESIA BERDASARKAN RETURN, RESIKO, DAN KOEFISIEN VARIASI

aktual yang diterima dengan return

keraguan investor muslim yang harapan.

Hartono (2012:227) menyatakan

bahwa return dan resiko memiliki

hubungan yang positif, artinya semakin besar resiko yang harus ditanggung, semakin besar return yang harus dikompensasikan. Hal ini sesuai dengan suatu kaidah ushul fiqh (Az-Zuhaili, 2006), yang mana disebutkan bahwa:

$$
\text { الغُرْمُ بالغُنْ }
$$

al-Gurmu bi al-Gunmi

Artinya: Keuntungan melekat pada resiko.

Dalam memilih suatu investasi pada reksadana, return dan resiko belum dapat mencerminkan kinerja reksadana mana yang lebih baik, karena pada kenyataanya reksadana selalu memiliki return dan resiko yang berbeda. Hartono (2012:232) menyatakan bahwa mempertimbangkan return dan resiko sebelum menentukan pilihan investasi dapat dilakukan dengan cara menghitung koefisien variasi. Brigham dan Joel (2009:238) mendefinisikan koefisien variasi sebagai resiko per unit return, yang dihitung dengan cara membagi standar deviasi dengan return ekspektasi.

Berdasarkan latar belakang dan penelitian sebelumnya yang telah diuraikan diatas, dapat dikatakan bahwa perkembangan reksadana syariah di Indonesia yang cukup pesat dalam beberapa tahun ini tentunya dapat menarik investor untuk berinvestasi pada reksadana syariah. Hadirnya reksadana syariah diharapkan dapat menjawab sebelumnya berinvestasi pada reksadana non-syariah yang masih terdapat riba dan prinsip-prinsip yang bertentangan prinsip syariah. Dengan adanya proses screening dalam pengalokasian aset dan cleansing pada pendapatan non-halal, reksadana syariah dipercaya mampu menghasilkan return yang tinggi dengan resiko yang rendah, serta menghasilkan koefisien variasi yang rendah, sehingga dipercaya dapat bersaing dengan reksadana nonsyariah. Oleh karena itu, peneliti akan melakukan penelitian dengan judul, "Perbandingan Return, Resiko, dan Koefisien Variasi pada Reksadana Syariah dan Reksadana Non-Syariah di Indonesia" untuk mengetahui apakah ada perbandingan yang signifikan antara return, resiko, dan koefisien variasi reksadana syariah dan non-syariah di Indonesia.

\section{LANDASAN TEORI}

Reksadana berasal dari kata "reksa" yang berarti jaga atau pelihara dan kata "dana" yang berarti uang (Sudarsono, 2007:200). Definisi reksadana menurut UU Pasar Modal no. 8 Tahun 1995 Pasal 1 Ayat 27 adalah wadah yang digunakan untuk menghimpun dana dari masyarakat pemodal untuk selanjutnya diinvestasikan dalam portofolio efek oleh Manajer Investasi.

Definisi reksadana syariah menurut Fatwa DSN No. 20/DSN-MUI/VI/2001 adalah reksadana yang beroperasi menurut ketentuan dan prinsip syariah Islam, baik dalam bentuk akad antara 
Syauqiyah, et al/ Jurnal Ekonomi Syariah Teori dan Terapan Vol. 5 No. 2 Februari 2018: 123-

134; PERBANDINGAN KINERJA REKSADANA SYARIAH DAN REKSADANA NON-SYARIAH DI

INDONESIA BERDASARKAN RETURN, RESIKO, DAN KOEFISIEN VARIASI

pemodal sebagai pemilik harta (sahib al-

pengelolaannya. Dana investor tidak

$\mathrm{mal} / \mathrm{rabb}$ al-mal) dengan manajer disimpan pada manajer investasi tetapi

investasi sebagai wakil sahib al-mal, maupun manajer investasi sebagai wakil sahib al-mal dengan pengguna investasi. Sama halnya seperti saham, reksadana syariah tidak menginvestasikan dananya pada kegiatan usaha yang bertentangan dengan syariat Islam. Adapun prinsipprinsip reksadana syariah menurut Sutedi (2011:151), yaitu:

1. Pemilihan portofolio investasi harus sesuai dengan syariah

2. Pelarangan riba

3. Pelarangan gharar

4. Larangan investasi pada makanan dan minuman yang haram

5. Prinsip keseimbangan agar manusia terhindar dari sikap serakah

6. Prinsip etika

7. Kepemilikan penuh dan pelarangan short selling.

Mekanisme reksadana syariah Sudarsono (2007) dalam Manan (2009:157) adalah:

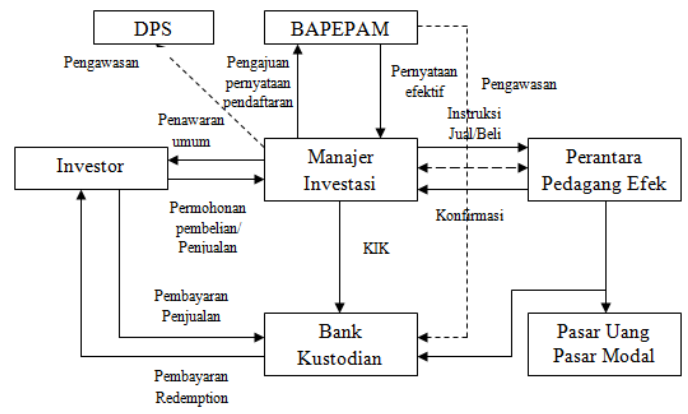

Menurut Huda dan Heykal (2010:265), mekanisme transaksi reksadana sudah mencerminkan transaksi Islam. Manajer Investasi hanya berfungsi sebagai pengelola dana yang memperoleh fee atas jasa pada pihak ketiga yang melakukan fungsi pemelihara harta yaitu, bank kustodian, dan bank kustodian pulalah yang melakukan administrasi perhitungan harta para investor.

Perbedaan yang fundamental antara reksadana syariah dan reksadana non-syariah terletak pada landasannya dalam pengelolaan aset. Kandarisa (2014:2) menyatakan bahwa perbedaan pokok antara reksadana syariah dan reksadana non-syariah adalah pada proses screening yang termasuk dalam proses pengalokasian aset. Penempatan aset pada reksadana syariah hanya dilakukan pada efek-efek yang telah sesuai dengan syariat Islam. Perbedaan pokok reksadana syariah dan reksadana non-syariah yang lainnya adalah terdapat proses cleansing pada reksadana syariah. Masruroh (2014) mendefinisikan proses cleansing sebagai sebuah proses untuk membersihkan semua sarana investasi dari unsur-unsur yang diharamkan, seperti pendapatan bunga yang masih terdapat dalam laporan laba rugi perusahan. Proses screening dan cleansing inilah yang tidak terdapat pada reksadana nonsyariah.

Perbedaan lainnya antara reksadana syariah dan reksadana nonsyariah adalah terletak pada manajer investasi. Reksadana syariah tidak hanya dikelola oleh manajer investasi yang profesional saja tetapi paham tentang kegiatan dalam pasar modal yang 
Syauqiyah, et al/ Jurnal Ekonomi Syariah Teori dan Terapan Vol. 5 No. 2 Februari 2018: 123-

134; PERBANDINGAN KINERJA REKSADANA SYARIAH DAN REKSADANA NON-SYARIAH DI

INDONESIA BERDASARKAN RETURN, RESIKO, DAN KOEFISIEN VARIASI

dilarang berdasarkan prinsip syariah (BEI,

dikompensasikan (Hartono, 2012:227),

2015:80). Untuk menjaga reksadana

syariah agar selalu berjalan sesuai dengan

prinsip syariah, maka diperlukan

pengawasan. Sutedi (2011:165)

menyatakan bahwa pengawasan

pengelolaan reksadana syariah tidak

hanya melalui otoritas jasa keuangan saja,

tetap terdapat Dewan Pengawas Syariah

(DPS) yang ikut mengawasi

keberlangsungan pengelolaan reksadana syariah.

Tandelilin (2010:9) menyatakan alasan utama orang berinvestasi adalah untuk memperoleh keuntungan. Suhartono dan Qudsi (2009:82) mendefinisikan return adalah tingkat keuntungan yang dinikmati pemodal atas suatu investasi yang dilakukannya. Sedangkan Sedangkan pengertian return investasi dalam Islam adalah sesuai dengan besarnya daya yang dikorbankan (Ryandono, 2009:69).

Selain return, resiko merupakan salah satu yang dapat dijadikan pertimbangan dalam membuat keputusan dalam berinvestasi. Definisi resiko menurut Tandelilin (2010:102) adalah kemungkinan perbedaan antara return aktual yang diterima dengan return harapan. Ryandono (2009:71) menyatakan bahwa resiko dalam investasi timbul karena adanya ketidakpastian waktu dan besarnya return yang akan diterima investor. Return dan resiko mempunyai hubungan positif, semakin besar resiko yang harus ditanggung, semakin besar return yang harus atau dalam kata lain high risk high return.

Investor selalu dihadapkan pada return dan resiko dalam memilih suatu portofolio. Jika ada dua portofolio yang memiliki return yang sama dengan resiko yang berbeda, maka portofolio yang dipilih investor adalah portofolio dengan resiko yang lebih rendah. Sebaliknya, jika ada dua portofolio yang memiliki return yang berbeda dengan resiko yang sama, maka portofolio yang akan dipilih investor adalah portofolio dengan return yang lebih tinggi. Tetapi pada kenyataannya, investor selalu dihadapkan pada dua portofolio yang memiliki return dan resiko yang berbeda, Maka yang harus dilakukan adalah mencari koefisien variasi. Brigham dan Joel (2009:238) menyatakan bahwa koefisien variasi adalah ukuran standar dari resiko per unit return, yang dihitung dengan cara membagi standar deviasi dengan return ekspektasi. Menurut Melicher dan Edgar (2003:333), nilai koefisien variasi yang tinggi menggambarkan bahwa resiko per unit return ekspektasi yang lebih besar. Sebaliknya jika nilai koefisien variasi yang rendah menggambarkan bahwa resiko per unit return yang lebih kecil.

\section{Hipotesis}

Penelitian ini memiliki tiga rumusan masalah, karena terdapat tiga variabel yang akan diteliti dalam penelitian ini, yaitu variabel return, resiko, dan koefisien variasi. Adapun jenis reksadana yang di teliti adalah sebanyak tiga jenis reksadana, yaitu reksadana saham, 
Syauqiyah, et al/ Jurnal Ekonomi Syariah Teori dan Terapan Vol. 5 No. 2 Februari 2018: 123-

134; PERBANDINGAN KINERJA REKSADANA SYARIAH DAN REKSADANA NON-SYARIAH DI

INDONESIA BERDASARKAN RETURN, RESIKO, DAN KOEFISIEN VARIASI

reksadana campuran, dan reksadana

pendapatan tetap. Maka, terdapat

sembilan hipotesis dalam penelitian ini,

yaitu:

$\mathrm{H}_{1.1}$ : Ada perbedaan yang signifikan antara return pada reksadana syariah saham dan reksadana non-syariah saham di Indonesia.

$\mathrm{H}_{1.2}$ : Ada perbedaan yang signifikan antara return pada reksadana syariah campuran dan reksadana nonsyariah campuran di Indonesia.

$H_{1.3}$ : Ada perbedaan yang signifikan antara return pada reksadana syariah pendapatan tetap dan reksadana non-syariah pendapatan tetap di Indonesia.

$\mathrm{H}_{2.1}$ : Ada perbedaan yang signifikan antara resiko pada reksadana syariah saham dan reksadana non-syariah saham di Indonesia.

$\mathrm{H}_{2.2}$ : Ada perbedaan yang signifikan antara resiko pada reksadana syariah campuran dan reksadana nonsyariah campuran di Indonesia.

$\mathrm{H}_{2.3}$ : Ada perbedaan yang signifikan antara resiko pada reksadana syariah pendapatan tetap dan reksadana non-syariah pendapatan tetap di Indonesia.

$\mathrm{H}_{3.1}$ : Ada perbedaan yang signifikan antara koefisien variasi pada reksadana syariah saham dan reksadana non-syariah saham di Indonesia.

$\mathrm{H}_{3.2}$ : Ada perbedaan yang signifikan antara koefisien variasi pada reksadana syariah campuran dan reksadana non-syariah campuran di Indonesia.

$\mathrm{H}_{3.3}$ : Ada perbedaan yang signifikan antara koefisien variasi pada reksadana syariah pendapatan tetap dan reksadana non-syariah pendapatan tetap di Indonesia.

\section{METODE PENELITIAN}

\section{Pendekatan Penelitian}

Pendekatan penelitian yang digunakan dalam penelitian ini adalah pendekatan kuantitatif.

\section{Definisi Operasional Variabel}

1. Return

Return merupakan keuntungan yang didapatkan investor atas investasi yang dilakukan. Berikut adalah persamaan untuk melakukan penghitungan return:

- Return Realisasi

$$
\mathrm{Rt}=\frac{\mathrm{NAB}_{\mathrm{t}}-\mathrm{NAB}_{\mathrm{t}-1}}{\mathrm{NAB}_{\mathrm{t}-1}}
$$

- Return Ekspektasi

$$
\mathrm{E}(\mathrm{Rt})=\frac{\sum \mathrm{Rt}}{\mathrm{n}}
$$

2. Resiko

Resiko merupakan selisih antara return actual dengan return harapan. Dalam, penelitian ini, standar deviasi digunakan untuk menghitung resiko. Berikut adalah persamaan Standar Deviasi:

$$
\sigma=\sqrt{\frac{\sum(\mathrm{Kt}-\mathrm{E}(\mathrm{R}))^{2}}{\mathrm{n}-1}}
$$

Keterangan:

$$
\begin{array}{ll}
\sigma & =\text { standar deviasi } \\
\mathrm{Ri} & =\text { return pada tahun ke- } \dagger \\
\mathrm{E}(\mathrm{R}) & =\text { return ekspektasi } \\
\mathrm{n} & =\text { jumlah periode }
\end{array}
$$

3. Koefisien Variasi 
Syauqiyah, et al/ Jurnal Ekonomi Syariah Teori dan Terapan Vol. 5 No. 2 Februari 2018: 123-

134; PERBANDINGAN KINERJA REKSADANA SYARIAH DAN REKSADANA NON-SYARIAH DI

INDONESIA BERDASARKAN RETURN, RESIKO, DAN KOEFISIEN VARIASI

Koefisien variasi merupakan resiko per

Berdasarkan kriteria yang telah

unit return. Berikut adalah persamaan

Koefisien Variasi:

$$
\mathrm{CV}=\frac{\sigma}{E(R)}
$$

Keterangan:

$$
\begin{array}{ll}
C V & =\text { koefisien variasi } \\
\sigma & =\text { Standar Deviasi } \\
E(R) & =\text { return ekspektasi }
\end{array}
$$

\section{Jenis dan Sumber Data}

Penelitian ini menggunakan jenis data sekunder, yaitu data NAB bulanan Reksadana Syariah dan Reksadana NonSyariah tahun 2013-2015 yang terdapat pada website aria.bapepam.go.id yang merupakan website sistem Aplikasi Industri Reksadana.

\section{Populasi dan Sampel}

Populasi yang digunakan pada penelitian ini adalah reksadana syariah dan reksadana non-syariah yang ada di Indonesia yang terdaftar di OJK pada periode 2013-2015. Teknik sampel yang digunakan adalah purposive sampling. Adapun kriteria pemilihan sampel penelitian ini adalah sebagai berikut:

a. Reksadana syariah dan reksadana non-syariah (berjenis reksadana campuran, saham, dan pendapatan tetap) yang telah tercatat di OJK.

b. Sampel yang digunakan memiliki data historis nilai aktiva bersih bulanan minimal mulai Januari 2013, yang tercatat pada website resmi aplikasi industri reksadana bapepam.

c. Sampel yang digunakan merupakan reksadana syariah dan reksadana non-syariah yang masih aktif.

disebutkan diatas, maka sampel yang akan digunakan dalam penelitian ini terdiri dari 15 reksadana syariah dan 15 reksadana non-syariah. Jenis reksadana yang akan diteliti meliputi 5 reksadana saham syariah maupun non-syariah, 5 reksadana pendapatan tetap syariah maupun non-syariah, 5 reksadana campuran syariah maupun non-syariah.

\section{Pengumpulan Data}

Pengumpulan data dapat dilakukan dengan cara melalui tiga tahap, yaitu:

1. Studi literatur, dengan cara membaca, mempelajari, dan mengumpulkan teori-teori yang ada dalam literatur atau bacaan yang terkait dengan permasalahan yang sedang dibahas pada penelitian ini.

2. Penelitian terdahulu, dengan cara melakukan peninjauan dan penelitian secara umum untuk mendapatkan informasi dan dapat mengetahui permasalahan yang sedang terjadi dalam penelitian ini.

3. Pengumpulan data sekunder, berupa nilai aktiva bersih reksadana syariah dan reksadana non-syariah yang diperoleh dari website resmi sistem Aplikasi Industri Reksadana yang dikelvarkan oleh Bapepam.

\section{Teknik Analisis Data}

Untuk membandingkan return, resiko, dan koefisien variasi, maka dilakukanlah beberapa langkah-langkah 
Syauqiyah, et al/ Jurnal Ekonomi Syariah Teori dan Terapan Vol. 5 No. 2 Februari 2018: 123-

134; PERBANDINGAN KINERJA REKSADANA SYARIAH DAN REKSADANA NON-SYARIAH DI INDONESIA BERDASARKAN RETURN, RESIKO, DAN KOEFISIEN VARIASI

untuk melakukan analisis dalam penelitian ini, yaitu:

1. Menetapkan sampel yang digunakan dalam penelitian ini

2. Menghitung return realisaisi, return ekspektasi, resiko, dan koefisien variasi.

3. Uji normalitas data dengan menggunakan uji One Sample Kolmogorov Smirnov dengan tingkat signifikansi sebesar $5 \%$.

4. Uji beda menggunakan Independent Samples T-Test untuk data yang berditribusi normal, dan uji beda menggunakan Mann Whitney Test untuk data yang tidak terdistribusi normal, dengan tingkat signifikansi sebesar $5 \%$.

\section{HASIL DAN PEMBAHASAN}

Hasil penelitian pada variabel return pada jenis reksadana saham menunjukkan nilai signifikansi sebesar $0,801>0,05$, sehingga dapat disimpulkan bahwa Ho diterima, atau dengan kata lain terdapat perbedaan yang tidak signifikan antara return reksadana syariah saham dan reksadana non-syariah saham di Indonesia pada periode 2013-2015. Hasil penelitian pada variabel return jenis reksadana campuran menunjukkan nilai signifikansi sebesar $0,748>0,05$, sehingga dapat disimpulkan bahwa $\mathrm{H}_{0}$ diterima, atau dengan kata lain terdapat perbedaan yang tidak signifikan antara return reksadana syariah campuran dan reksadana non-syariah campuran di Indonesia pada periode 2013-2015. Hasil penelitian pada variabel return jenis reksadana pendapatan tetap menunjukkan nilai signifikansi sebesar $0,796>0,05$, sehingga dapat disimpulkan bahwa $\mathrm{H}_{0}$ diterima, atau dengan kata lain terdapat perbedaan yang tidak signifikan antara return reksadana syariah pendapatan tetap dan reksadana nonsyariah pendapatan tetap di Indonesia pada periode 2013-2015.

Terdapat perbedaan yang tidak signifikan pada return reksadana syariah saham dan reksadana non-syariah saham di Indonesia mengindikasikan bahwa reksadana syariah dapat menghasilkan return yang sama besarnya dengan reksadana non-syariah. Hal ini dapat disebabkan oleh hampir samanya faktorfaktor yang mempengaruhi return reksadana syariah dan reksadana nonsyariah, kecuali faktor suku bunga.

Hasil penelitian pada variabel resiko pada jenis reksadana saham menunjukkan nilai signifikansi sebesar $0,901>0,05$, sehingga dapat disimpulkan bahwa $\mathrm{H}_{0}$ diterima, atau dengan kata lain terdapat perbedaan yang tidak signifikan antara resiko reksadana syariah saham dan reksadana non-syariah saham di Indonesia pada periode 2013-2015. Hasil penelitian pada variabel resiko jenis reksadana campuran menunjukkan nilai signifikansi sebesar 0,460>0,05, sehingga dapat disimpulkan bahwa $\mathrm{H}_{0}$ diterima, atau dengan kata lain terdapat perbedaan yang tidak signifikan antara resiko reksadana syariah campuran dan reksadana non-syariah campuran di Indonesia pada periode 2013-2015. Hasil penelitian pada variabel resiko jenis 
Syauqiyah, et al/ Jurnal Ekonomi Syariah Teori dan Terapan Vol. 5 No. 2 Februari 2018: 123-

134; PERBANDINGAN KINERJA REKSADANA SYARIAH DAN REKSADANA NON-SYARIAH DI INDONESIA BERDASARKAN RETURN, RESIKO, DAN KOEFISIEN VARIASI

reksadana pendapatan tetap

reksadana.

Karim

(2014:276)

menunjukkan nilai signifikansi sebesar

$0,656>0,05$, sehingga dapat disimpulkan

bahwa $\mathrm{H}_{0}$ diterima, atau dengan kata lain

terdapat perbedaan yang tidak signifikan

antara resiko reksadana syariah

pendapatan tetap dan reksadana non-

syariah pendapatan tetap di Indonesia

pada periode 2013-2015.

Wahyudi, dkk (2013:4) membagi

resiko menjadi dua, yaitu Resiko tidak sistematis dan resiko sistematis. Resiko tidak sistematis merupakan resiko yang terjadi akibat faktor-faktor yang hanya terjadi pada institusi tertentu, atau dapat dikatakan resiko ini merupakan resiko yang unik. Memiliki komposisi investasi yang hampir serupa pada setiap jenis reksadananya memiliki arti bahwa tidak adanya faktor unik dalam pembentukan portofolio investasi sehingga menyebabkan terdapat perbedaan yang tidak signfikan antara resiko reksadana syariah campuran dan reksadana nonsyariah campuran. Sedangkan resiko sistematis dapat dikatakan sebagai resiko yang muncul akibat adanya variabel makroekonomi atau kondisi sektoral atau geografis atau indikator pasar lainnya. Jika dilihat pada hasil uji hipotesis, maka dapat disimpulkan bahwa faktor-faktor makroekonomi yang mempengaruhi resiko reksadana syariah campuran dan reksadana non-syariah campuran adalah sama, kecuali faktor suku bunga.

Resiko kepatuhan syariah juga dapat menjadi salah satu resiko yang terjadi dalam berinvestasi pada mendefinisikan resiko kepatuhan sebagai resiko yang disebabkan oleh tidak dipatuhinya ketentuan-ketentuan yang ada, baik secara internal maupun secara eksternal, sehingga dapat diartikan bahwa resiko kepatuhan syariah merupakan resiko yang terjadi akibat dari tidak dipatuhinya ketentuan-ketentuan syariat yang ada. Resiko ini dapat terjadi apabila seorang muslim berinvestasi tidak berpedoman pada syariat Islam, seperti Fatwa DSN-MUI No. 20 tentang reksadana dan Fatwa DSN-MUI No. 40 tentang pasar modal.

Hasil penelitian pada variabel koefisien variasi pada jenis reksadana saham menunjukkan nilai signifikansi sebesar 0,597>0,05, sehingga dapat disimpulkan bahwa $\mathrm{H}_{0}$ diterima, atau dengan kata lain terdapat perbedaan yang tidak signifikan antara koefisien variasi reksadana syariah saham dan reksadana non-syariah saham di Indonesia pada periode 2013-2015. Hasil penelitian pada variabel koefisien variasi jenis reksadana campuran menunjukkan nilai signifikansi sebesar 0,457>0,05, sehingga dapat disimpulkan bahwa $\mathrm{H}_{0}$ diterima, atau dengan kata lain terdapat perbedaan yang tidak signifikan antara koefisien variasi reksadana syariah campuran dan reksadana non-syariah campuran di Indonesia pada periode 2013-2015. Hasil penelitian pada variabel koefisien variasi jenis reksadana pendapatan tetap menunjukkan nilai signifikansi sebesar 0,444>0,05, sehingga 
Syauqiyah, et al/ Jurnal Ekonomi Syariah Teori dan Terapan Vol. 5 No. 2 Februari 2018: 123-

134; PERBANDINGAN KINERJA REKSADANA SYARIAH DAN REKSADANA NON-SYARIAH DI

INDONESIA BERDASARKAN RETURN, RESIKO, DAN KOEFISIEN VARIASI

dapat disimpulkan bahwa Ho diterima,

atau dengan kata lain terdapat

perbedaan yang tidak signifikan antara

koefisien variasi reksadana syariah

pendapatan tetap dan reksadana non-

syariah pendapatan tetap di Indonesia pada periode 2013-2015.

Terdapat perbedaan yang tidak siginfikan antara keofisien reksadana syariah saham dan reksadana non-syariah saham merupakan salah satu bukti perkembangan ekonomi syariah di Indonesia (Ratnawati dan Khairani, 2012:111). Selain itu, hasil tersebut membuktikan bahwa proses screening dan cleansing tidak membuat kinerja suatu reksadana menjadi rendah, sehingga kinerja reksadana syariah mampu bersaing dengan kinerja reksadana non-syariah. Karena reksadana syariah memiliki kinerja yang sama bagusnya dengan reksadana non-syariah, sebagai seorang investor muslim diwajibkan untuk berinvestasi pada reksadana syariah karena telah jelas kehalalannya dan secara religius dapat dipertanggungjawabkan.

\section{v. SIMPULAN}

Kesimpulan yang dapat ditarik dari hasil uji yang dilakukan dalam penelitian ini adalah:

1. Terdapat perbedaan yang tidak signifikan antara return reksadana syariah saham dan reksadana nonsyariah saham di Indonesia periode 2013-2015 pada tingkat signifikansi 5\% $(a=0,05)$.
2. Terdapat perbedaan yang tidak signifikan antara return reksadana syariah campuran dan reksadana non-syariah campuran di Indonesia periode 2013-2015 pada tingkat signifikansi $5 \%(a=0,05)$.

3. Terdapat perbedaan yang tidak signifikan antara return reksadana syariah pendapatan tetap dan reksadana non-syariah pendapatan tetap di Indonesia periode 2013-2015 pada tingkat signifikansi $5 \%(a=0,05)$.

4. Terdapat perbedaan yang tidak signifikan antara resiko reksadana syariah saham dan reksadana nonsyariah saham di Indonesia periode 2013-2015 pada tingkat signifikansi 5\% $(a=0,05)$.

5. Terdapat perbedaan yang tidak signifikan antara resiko reksadana syariah campuran dan reksadana non-syariah campuran di Indonesia periode 2013-2015 pada tingkat signifikansi $5 \%(a=0,05)$.

6. Terdapat perbedaan yang tidak signifikan antara resiko reksadana syariah pendapatan tetap dan reksadana non-syariah dan pendapatan tetap di Indonesia periode 2013-2015 pada tingkat signifikansi $5 \%(a=0,05)$.

7. Terdapat perbedaan yang tidak signifikan antara koefisien variasi reksadana syariah saham dan reksadana non-syariah saham di Indonesia periode 2013-2015 pada tingkat signifikansi $5 \%(a=0,05)$. 
Syauqiyah, et al/ Jurnal Ekonomi Syariah Teori dan Terapan Vol. 5 No. 2 Februari 2018: 123-

134; PERBANDINGAN KINERJA REKSADANA SYARIAH DAN REKSADANA NON-SYARIAH DI

INDONESIA BERDASARKAN RETURN, RESIKO, DAN KOEFISIEN VARIASI

8. Terdapat perbedaan yang tidak signifikan antara koefisien variasi reksadana syariah campuran, dan reksadana non-syariah campuran di Indonesia periode 2013-2015 pada tingkat signifikansi $5 \%(a=0,05)$.

9. Terdapat perbedaan yang tidak signifikan antara koefisien variasi reksadana syariah pendapatan tetap dan reksadana non-syariah pendapatan tetap di Indonesia periode 2013-2015 pada tingkat signifikansi $5 \%(a=0,05)$.

Saran yang dapat disampaikan dari simpulan diatas yaitu:

a. Bagi Investor

Sebagai investor muslim, diwajibkan bagi kita untuk mentaati syariat Islam dan memperhatikan kehalalan dalam berinvestasi, salah satunya dapat berinvestasi pada reksadana syariah. Saat ini, reksadana syariah telah terbukti memiliki kinerja yang baik dan mampu bersaing dengan reksadana non-syariah. Pengelolaan reksadana syariah juga sudah terbukti sesuai dengan prinsip syariat Islam, sehingga tidak ada alasan lagi untuk tidak berinvestasi pada reksadana syariah.

b. Bagi Perusahaan Manajer Investasi Meningkatkan kinerja reksadana yang bernilai minus dengan cara menghitung kembali komposisi investasi yang ditawarkan sehingga menghasilkan return yang lebih tinggi dan resiko yang rendah.

c. Bagi Peneliti Selanjutnya

Penelitian ini masih jauh dari kata sempurna. Maka ada baiknya penelitian ini dikembangkan, misalnya perbandingan return, resiko, dan koefisien variasi pada jenis reksadana lainnya, seperti reksadana pasar uang atau reksadana terproteksi. Selain itu, dapat pula dilakukan perbandingan kinerja reksadana pada saat kondisi perekonomian di Indonesia pada saat bullish dan bearish, dan mengembangkan waktu penelitian pada penelitian selanjutnya.

\section{DAFTAR PUSTAKA}

Brigham, Eugene dan Joel F. Houston. 2009. Fundamental of Financial Management $12^{\text {th }}$ Edition. USA: SouthWestern Cengage Learning

Bursa Efek Indonesia. 2015. Sekolah Pasar Modal Syariah. Jakarta

Hartono, Jogiyanto. 2012. Teori Portofolio dan Analisis Investasi. Yogyakarta: BPFE Yogyakarta

Hirt, Geoffrey A. dan Stanley B. Block. 1999.

Fundamentals of Investment Management. Singapore: McGraw-Hill Book Co.

Huda, Nurul dan Mohamad Heykal. 2010. Lembaga Keuangan Islam. Jakarta: Kencana

Kandarisa, Nur Aini. 2014. Perkembangan dan Hambatan Reksadana Syariah di Indonesia: Suatu Kajian Teori. Jurnal Akuntansi Unesa Vol 2, No 2

Karim, Adiwarman A. 2014. Bank Islam: Analisis Fiqih dan Kevangan. Jakarta: Raja Grafindo Persada 
Syauqiyah, et al/ Jurnal Ekonomi Syariah Teori dan Terapan Vol. 5 No. 2 Februari 2018: 123-

134; PERBANDINGAN KINERJA REKSADANA SYARIAH DAN REKSADANA NON-SYARIAH DI INDONESIA BERDASARKAN RETURN, RESIKO, DAN KOEFISIEN VARIASI

Manan, Abdul. 2009. Aspek Hukum dalam

Penyelenggaraan Investasi di Pasar

Modal Syariah Indonesia. Jakarta:

Kencana

Masruroh, Aini. 2014. Konsep Dasar Investasi Reksadana. Jurnal Universitas Islam Negeri Jakarta

Melicher, Ronald D. dan Edgar A. Norton. 2003. Finance: Introduction to Institutions, Investment, and Management. USA: John Wiley \& Sons, Inc.

Ratnawati, Vince dan Ningrum Khairini. 2012. Perbandingan Kinerja Reksadana Syariah dan Reksadana Konvensional. Jurnal Akuntansi Vol 1, No 1

Ryandono, M. Nafik Hadi. 2009. Bursa Efek dan Investasi Syariah. Jakarta: Serambi

Sudarsono, Heri. 2007. Bank dan Lembaga Kevangan Syariah. Yogyakarta: Ekonisia Suhartono dan Fadlillah Qudsi. 2009. Portofolio Investasi dan Bursa Efek. Yogyakarta: UPP STIM YKPN

Sutedi, Adrian. 2011. Pasar Modal Syariah. Jakarta: Sinar Grafika

Tandelilin, Eduardus. 2010. Portofolio dan Investasi, Teori dan Aplikasi. Yogyakarta: Kanisius

Wahyudi, Imam dkk. 2013. Manajemen Risiko Bank Islam. Jakarta: Salemba Empat 